\title{
THE DEVELOPMENT OF PRIVATE INTERNATIONAL LAW THROUGH CONVENTIONS
}

\author{
Professor D. Josephus Jitta
}

Councillor of State at the Hague

My purpose. I intend to study the influence of the great war on private international law, the last expression being taken in the sense of the law relating to private juridical relations in a juridical community larger than a nation or State. Two undeniable facts are to be placed in the foreground. The first is, that the long and bloody struggle has spread the seeds of hatred and distrust among the nations; the second fact is that the supranational social life, the source of international juridical relations between the members of the various nations, is going on, in spite of the recent war. ${ }^{1}$ The fact is an impediment to the universal development of private international law; the second, on the contrary, stimulates its development, as no social life is possible without rules of law. The problem is therefore to determine how the contradictory action of the impeding influence and the stimulating one may impel the world in an interjacent direction. I shall try to solve this problem, not as a prophet, but simply as an observer of the phenomena of life, inducing future events from the lessons of the past and the present.

Hatred and distrust, as results of the great war. Hatred and distrust are feelings. As such, they are not to be reasoned away, but they are able to be tested by an impartial observer. Hatred is the pleasant feeling attached to the ruin of a fellow man. Distrust is the repugnance to coöperate with him, on account of the supposed depravity of his character. Indubitably such feelings proceed from a war, but a coolheaded examination will show that they are neither general nor lasting. As to the attribute "general," it is clear that the above mentioned unfriendly feelings do not extend to members of nations which have been allies; and, in so far as neutral individuals are concerned, that not all the members of a neutral nation can be objects of hatred and distrust. With regard to the attribute "lasting," the human heart is too small for a lasting hatred and a general distrust, the object of which embraces the millions of individuals, belonging to nations with which the native country, in a more or less remote past, has been at war. If, in the beginning, hatred may be directed to a foreign nation as a collectivity, a discrimination will soon be made between the collectivity and the individuals within it, and with regard to the individuals, between husk and grain. When hatred is spread over a million of

\footnotetext{
${ }^{1}$ See the lucid observations on the private international law of the future
} made by Antoine Pillet in (IgI7) 26 YaLE LAw Journal, 63r. 
fellow men, each individual is only the object of a millionth of solid hatred. My conclusion is that in the future struggle between hatred and love, love will "win the war" because love is divine and high and hatred human and vile.

The supranational life is going on, in spite of the great zvar. It is going on because men are social beings and mankind is a social community. Family relations as well as commercial relations are universal on account of the higher unity of mankind. Family relations have existed a long time before the war between the sons and daughters of the various nations, new relations were entered into during the war and have come into existence after it. Even the fact that husband and wife-or bridegroom and bride-belong to nations which have been at war with each other, is not always destructive of love. There also, in the struggle between hatred and love, love will "win the war." Marriages, moreover, between two subjects of nations, which have been allies, and marriages of such subjects with neutrals have been frequently concluded during the war, more frequently even than before. Such unions have created and will raise in the future many questions of private international law, concerning marriage, ${ }^{2}$ marriage settlements, divorce, legitimacy, guardianship, succession, etc. As to commercial relations, the universality of social life is at least as obvious. Not every part of the world is able to bring forth the same productions of the soil. Some countries are producing too much, others too little. Mines are not to be found everywhere. The great war has even accentwated the interdependence of the nations. Exportations and importations are of vital interest everywhere, and no system of protective duties is able to check entirely the development of international trade. Merchants, of course, are not angels, but, generally speaking, commerce cannot flourish without due regard for contracts and performance in good faith of assumed obligations. If such is the case, private juridical relations in the domain of trade necessitate the aegis of the law. Such an international law includes contracts in general, contracts of sale of goods especially, partnerships and companies, banking, insurance, etc. The questions relative to the observance and bona fide performance of contracts embrace the jurisdiction of courts in civil matters, the practice of courts with reference to aliens, execution, bankruptcy, etc. In times of peace, moreover, even if peace should remain in.future times only an interval more or less long between wars, individuals are, in general, free to choose freely a domicil. If they emigrate, existing juridical relations formed in the domicil of origin remain in existence, and new relations can be entered into in the country of the new domicil. Summa summarum, the development of private juridical relations between individuals, after the great war,

\footnotetext{
${ }^{2}$ See the leading cases discussed in Baty, Capacity and Form of Marriage in the Conflict of.Laws (rgr7) 26 ibid., 444.
} 
is not a subject of reasonable doubt. The connection between factual social relations and juridical rules is the same as that between iron and iron-stone; the latter attracts the former.

Private international law is, in a certain sense, a part of the law of a country, but it is above that something else. The conception that private international law should exclusively be a part of the law of a country is a too narrow conception. Private international law is certainly a matter of national regulation, it includes directions, given by the lawgiver of a country to the courts of the same country, for their guidance in matters connected with aliens, foreign laws and foreign judgments. But private international law may be considered from a higher point of view, that of a union of nations, or States in the American sense, and even from the point of view of the collectivity of nations, acting as the public power of mankind and able to give to mankind universally working regulations. We have to discriminate, therefore; a national branch of private international law, and an international or universal branch. As to the national branch, I have a few observations to make. Many nations, France, the Netherlands and Italy, for instance, have inserted in their national laws or codes regulations concerning aliens, foreign laws, foreign judgments, etc. In England and in the United States, some rules have also been settled. The courts will have frequently to apply these statutes and rules after the war. But the international social life is so intricate that in the future very often questions of private international law will arise, for which neither written nor unwritten rules will present a direct solution. Within their sphere of jurisdiction in civil matters the courts will have nevertheless to give solutions, and the basis of such solutions can only be the necessity of insuring a reasonable social intercourse between all the individuals, members of mankind. In so far there is, apart from the national basis, an international-common basis of private international law.

Comparative private international laze. If there is, let it be only in a particular sense, a French, Italian, Dutch or English private international law, a comparison between the various national regulations of the same subject-matter will be highly interesting and practically important. This study will lead gradually to an improvement of the national statutes and of the rules of the case-law. Such a comparison will afford a touchstone of the righteousness of the positive law, this touchstone being the necessity of insuring a reasonable social intercourse between all the individuals, members of mankind.

Collective international regulations. The comparative studies, mentioned under the foregoing rubric, will lead in the end to a universal adoption of the best rules. Such a uniformity would centainly promote what we have called a reasonable social intercourse between all the individuals, members of mankind. But the uniformity is only attainable after many centuries, as the impediments of the evolution are very, 
very great. The chief impediment is the variety of the civil and commercial laws of the nations, and the strong attachment of each nation to the time-honored laws, inherited from the ancestors and forming a part of the national treasure, common to the members of a nation. This national conservatism has a large influence on the principles of private international law, applied in a riation. The consideration that the subjects of a country may not be allowed to evade their national laws by choosing a domicil in a foreign country-it is even often called a fraud-leads to a rule purporting that the subjects of a country are bound by the national laws, even when they have fixed a final abode in a foreign country. 'Such a rule is often called the principle of nationality. The same conviction of the perfection of the time-honored national law prevents the admission of a rule, which would leave aliens, permanently or even temporarily domiciled in a country, completely subject to the laws of their nation of origin. Such a rule is not seldom called the principle of public policy. The authority of the principle of nationality is denied in many countries, which are clinging to the principle of the domicil, permanently or at least seriously established. Such contrarieties are highly detrimental to the reasonable social intercourse between the members of mankind. Each nation, moreover, considers itself as absolutely free with regard to the regulation of the jurisdiction of its own courts, but if the various national regulations are in contradiction with each other, and if some nations extend beyond reasonable limits the jurisdiction of the national judiciary in civil matters, a sound regulation of the effects of foreign judgments is nearly impossible. In this way, as a consequence of nearly insoluble difficulties, the idea of collective international regulations of private international law made its appearance in the world.

Generalities as to the form of collective international regulations. The establishment of a world parliament, either with a single house of representatives, or with two houses, viz., an indirectly elected house of nations and a directly elected house of representatives, but in every case with a majority able to make decisions, may be considered as an idea, deserving the attention of-scientists, but it is not ripe in our days. Such being the case, universally working statutes are unattainable. Collective international regulations have to follow side-paths. One of these is the promulgation of identical national regulations in the various nations or states, a way well known in the United States, where the legislative power of the Union has constitutional limits. ${ }^{3}$ The method of identical national laws seems very simple. It is not subject to any theoretical objection, as it does not bring along with it the slightest encroachment upon the absolute sovereignty of a national

\footnotetext{
'With reference to the limitations of the federal government of the United States, see Dodd, Implied Pozvers and Implied Limitations in Constitutional Law (I9I9) 29 YaLe Law JournaI, I37. I5I.
} 
legislative power. But it is by no means easy to put the method into practice, on account of the obstinate conservatism of the nations. And so the nations have used, not only for international administrative matters, but also in the domain of private international law, another method, consisting in the conclusion of international treaties, and especially laze-making treaties, viz., treaties not only binding upon the nations as such, but also upon the individuals and the courts having jurisdiction in civil matters. Such a law-making treaty is a substitute for a universal ordinance. The method of law-making treaties is by no means free from theoretical objections. The principal objection is the binding power of a treaty, concluded between nations, for the individuals. A second difficulty is the relation between a law-making treaty and previous or subsequent national statutes, regulating the same matter. A third knotty problem is the relation between the power to conclude international treaties, exercised in a union by the federal organs, and the legislative autonomy of the united nations or states. The method of concluding treaties, nevertheless, has a practical advantage, stronger than the theoretical objections, since it affords the possibility of arrangements and mutual concessions, by which nations sacrifice a part of their national conservatism in order to insure the reasonable international intercourse. Speaking generally, the method of identical national laws seems more appropriate for matters requiring an exhaustive regulation, for instance, in the case of negotiable instruments, whilst treaties are preferable, when the harmonious application of differing national laws is the only thing in view, as, for example, in the matter of divorce. A combination of the two methods is not excluded. It may be that the nations are only bound by the treaty to enact or at least to propose to the national legislative power a bill, framed in accordance with the treaty. Such a combination of an international treaty and uniform national laws has been attempted at the Hague conferences of rgIo and I912, concerning bills of exchange and cheques. The draft-treaty of I9I2 has not yet been ratified, but previous treaties, elaborated in the Hague and relating to private international law, are in force in our days, although their power has been weakened by the withdrawal of some of the nations. This withdrawal has nothing to do with the war, but it may be apprehended that the influence of the war will be unfavorable to the whole system of the Hague treaties. It is therefore a matter properly within the scope of my subject to consider if the work of the Hague, in the domain of private international law, can be consolidated or even extended, after the great war.

In remembrance of my former study of the Hague treaties concerning private international law. I cannot presume, after so many years and so many tremendous events, that the paper which I read at the Universal Congress of Lawyers and Jurists at St. Louis, Mo., in I904, is still familiar to the American juridical world. So I take the liberty 
to introduce myself a second time. The object of the present study, however, is not the same as that of my former paper. At St. Louis, I had to give a review of the Hague conferences and treaties, whilst now I have to examine especially the influence of the great war. As we have seen, private international law, as a practical science, has not lost its importance in consequence of the war. It may even be expected that one of the objects of the "league of nations" will be to promote a reasonable intercourse between individuals.

Division of the examination of the said treaties. I shall consider, in the first place, the form of the Hague treaties, and, in the second place, the general principles on which their provisions are based.

Their form. Of course, the Hague treaties concerning private international law are treaties. They have the form of covenants between nations, and the expression "the contracting States" is continually used in the instruments. The intention of the contracting States, however, has been that the treaties should have the effect of laws or statutes, binding the individuals and modifying, without further measures, the existing laws, statutes or settled rules, relating to the same matters. In so far as the contracting States are unanimous regarding this interpretation, the result aimed at will be attained, but if there is a doubt in some of the contracting States, the efficiency of the treaties will be seriously impaired in these States, and if the adherence of new States is contemplated, the question will arise with regard to these new contracting parties. It is necessary, therefore, to reconsider the question of the form. The treaty, elaborated with regard to bills of exchange, has met the difficulty in part. It has divided the subject-matter in two parts, viz., a treaty and a uniform regulation. The contracting States are bound by the treaty, but they are bound to enact, in their respective realms, a law corresponding-apart from a limited number of reservations-with the uniform regulation, annexed to the treaty. One of the advantages of this mixed system is that the uniformity can be limited to the main points, ripe for such a uniformity, but it is not certain that such a mixed system will overcome all the difficulties. One of these difficulties, and certainly a most important one for the United States, is the limitation of the power of the Union, as a contracting party. Even if a distinction is made between real international relations between individuals and exhaustive international regulations of a matter like negotiable instruments, there is at least a serious doubt as to the power of the Union to bind the legislative powers of the states of the Union. Two statements in this sense were made by the American delegate in Igro. ${ }^{4}$ A way out of this difficulty has to be found. I beg to suggest that the obligation of the contracting States should be limited to a serious attempt to put in force a national law corresponding to the uniform regulation

'U. S. Sen. Doc. No. 768, 6rst Cong., 3d sess. 319-322. 
annexed to treaty. The points with regard to which the freedom to diverge is authorized, would have to be fixed in the treaty. In such a way a participation of all the States of the world would be possible.

Summary of the general principles. of the Hague treaties relating to marriage, effects of marriage, divorce, guardianship and lunacy. I am setting the above mentioned five treaties apart from the treaty concerning civil procedure and from the draft-treaty relating to bills of exchange. The treaty concerning civil procedure has no general principle, it contains only special provisions, to which a special rubric will be devoted below. The draft-treaty relating to bills of exchange is only the introduction to a uniform regulation of the subject-matter. As to the five treaties which I place in the foreground, I shall consider the two following general principles.

The principle purporting that the only aim of private international law is the solution of conflicts of law. My intention is not to. develop theories concerning the nature and the method of private international law. In my former works I have often supported the thesis that the solution of the conflicts of law is by no means the only aim of private international law, but only an expedient, which may eventually lead to a reasonable rule for the international social intercourse of all the individuals, members of mankind. According to my opinion, private international law is the private law, considered from a point of view larger than that of a single nation. But here I have only to consider the matter as a practical doctrine. I have only to emphasize by way of introduction, that the utmost exaggeration of the narrow theory of the conflicts of law is to be found in the old and celebrated but obsolete theory of the three "Statutes." The said theory divides the law in three categories, viz., personal, real and mixed laws, and refers, for personal laws to the domicil-or nationality-of a person, for real laws to the situation of a thing, and for mixed laws to the place of an act of men. In this way three general principles are sufficient for the solution of all the conflicts of law. In England and in the United States this narrow and mechanical conception has never been admitted, and even on the European continent it may be considered as dead, although it has not been buried. Relics of the theory are to be found in modern sets of rules for the solution of conflicts. The number of the rules for such solutions has been increased; not only have general principles been framed for persons, things and acts, but scientists and lawgivers have entered into particulars. Rules have been framed for status and capacity of persons, marriage, personal and patrimonial effects of marriage, divorce, guardianship, immovable and movable things, contracts, negotiable instruments, torts, evidence, etc. It is clear that such a specialization is an amelioration. But the system of the general principles for the solution of conflicts is nevertheless defective. It leads to mechanical solutions and lays too much emphasis upon the claims of the lawgivers and pays too little attention to the 
reasonable requirements of international social life. Great honor is due to the framers of the Hague treaties; they have neither adopted the old theory nor followed mechanically the modern system of the set of general rules. They have specialized to a very large extent, but if a revision of the Hague treaties is planned, in order to make the regulations acceptable for the Anglo-American world, it will be necessary to go further, and to avoid, as. much as possible, general rules referring to a law. So, for instance, rules referring in general to the national law of a person have to be considered again.

The principle of nationality, compared with the principle of domicil. In many countries the status and capacity of persons, and even more generally the personal rights, including succession, are considered as governed by the national law of the person concerned. Sometimes an exception almost as broad as the rule itself is admitted, to the effect that foreign laws, which in the opinion of the court are contrary to public policy or to morality, are not applied. The exception is not quite as large as the rule with which it is connected, because no court will consider a statute of its own country as opposed to public policy or morality. Only foreign laws, therefore, are affected by the exception. The above mentioned rule, with its exception, constitutes, in private international law, the so-called principle of nationality. In other countries, and especially in the United States, where the civil laws of the States are not identical and where there is no "national law" common to all the American citizens, the principle of domicil governs, generally speaking, the cases which elsewhere are controlled by the principle of nationality. The same reason prevents the application of the principle of nationality in countries possessing autonomous colonies. It must be emphasized that domicil, in the American and also with a few gradations in the English sense, is not simply the principal abode of a man, but the abode established with a final aim. The opposition between the principle of nationality and that of domicil is nearly insuperable. It is not absolutely insuperable, as I hope to show.

The limitations of the principle of nationality in the Hague treaties. The principle of nationality is undoubtedly the leading thought of the Hague treaties, especially in the matters of marriage and divorce. But a few small concessions have been made to the principle of domicil. The treaty concerning marriage has admitted, in the first place, the system of the so-called "renvoi" or pointing-back, well known to the American juridical world by the able studies of Professor Lorenzen. ${ }^{5}$ The domiciliary law of a person is applied when the national law of the person contains a rule referring to the domiciliary law. I am not an advocate of the pointing-back-theory, but I admit that, in some

\footnotetext{
${ }^{3}$ See particularly (1918) 27 Yale Law Journal, 509, 53I; (19I9) 29 ibid., 214.
} 
cases, this unsound theory can afford a reasonable limitation of a rule, by which a conflict is solved in too mechanical a way. In the second place, the Hague treaties have specialized, to a very large extent, the rules based on the principle of nationality and even more accurately than the rule, the exceptions. The expressions "public policy" and "morality" have been carefully avoided in the treaties, but in many cases, especially with reference to the conditions of a valid marriage, treaties have determined how far a State may depart from the national law of a person, either in order to prevent a marriage, admitted by the national law, or to admit it in cases prohibited by the same law. We find, therefore, in the Hague treaties the germs of a compromise between the two principles.

Would it be possible to frame a treaty, acceptable to the advocates of nationality as well as those of domicil? As long as the civil laws of the nation rest on the present bases it is not likely to be expected that one of the principles will be abandoned in favor of the other. In many countries, the rules relating, for instance, to the conditions of a valid marriage or to the admissibility of a divorce, limit the liberty of men to such an extent, in the real or supposed interest of the local political community, that the lawgiver cannot permit his own subjects to evade their national laws by choosing a domicil in a foreign country. In such a case the lawgiver must adhere to the principle of nationality, at least with regard to his own subjects, domiciled abroad. On the other side, the principle of nationality is not acceptable in some countries. ${ }^{\circ}$ Therefore, in our days, an attempt to come to a universal agreement, based either on nationality or on domicil, must necessarily fail. The extreme logical conclusion, from this state of the world's affairs, would be the division of the world into two groups, each of them attached to a different principle. If such a division would lead to two parallel unions of nations, such a division would be, if not an improvement, at least a consolidation of the present state of the world. But I venture to say that something more can be done. Between nationality and domicil, as this last conception is understood in the Anglo-American world, there is a link, the domicil of origin, to which the American and English laws turn back when there is no domicil fixed as a final abode. Not always will such a domicil of origin coincide with nationality, but such may be the case. A stipulation in a treaty, allowing the contracting States a choice between the principle of nationality and that of the domicil, in the Anglo-American sense, is to be taken into serious consideration. Such a choice would be only a small amelioration, if the nations would cling to the doctrine that the only aim of private international law is to solve conflicts between laws, but, if the aim is really to insure the reasonable social intercourse between all

\footnotetext{
- For the position taken by the United States, see I Wharton, Conffict of Lazus (3d ed. Ig05) sec. 8.
} 
the individuals, members of mankind, many rules, avoiding a general reference to a law, would be acceptable to the supporters of the principle of nationality as well as to the opposition. As to the marriage of aliens, the conditions which every State is bound to control and entitled to impose, would be determined. With regard to the patrimonial effects of marriage, the rule could be admitted, that when a marriage is concluded between parties belonging to various nations, no change in the fortunes will take place by the simple fact of the union. As to divorce, the equal rights of husband and wife could be insured; the wife could be authorized to sue before the court of the last common domicil, if the husband is guilty of grave misconduct. Divorce, of course, is a thorny matter in private international law, but the Hague treaties have shown that where there is a will there is a way. With reference to infants needing protection, a regulation could be based on the principle that the main point is not to determine the law governing guardianship, but to insure an efficacious protection under all circumstances. Many things can be done in this way, even in the domain of the family law. and the succession law, where the conservatism of the nations is so obstinate. But however, important the family law and the succession law may be, there are other domains on which I have to fix the attention, viz., the law of obligations and contracts and the law of civil procedure. It is easy to make clear that, with regard to the two matters last mentioned, the solution of conflicts of law is by no means the main point.

Obligations and contracts in private international law. No war can interrupt in the long run the international business life. Some rules of the international law of contracts are a part of the common commercial law of the world. The laws of the nations, of course, are not entirely identical, and so the scientists, clinging to the doctrine of the conflicts of law, have attempted to fix, by means of a general rule, the law governing obligations and contracts in private international law. The great number of general rules, discovered by the scientists, is a demonstration of the unfitness of the method, which. regards the question as a conflict of laws, which can be solved by a general reference to one of the conflicting laws. The general application of the law of the place where a contract or obligation was entered into, has found supporters, but the law of the place of performance has also found strong advocates. Other scientists favor the national or domiciliary law, common to the parties, or, in case of disparity, the national or domiciliary law of the debtor. It has been suggested that the law, to which the intention of the parties-at least in the matter of contracts-is directed, is paramount, - a law which, in many cases, has to be determined by a presumption, as parties do not express any common intention to refer to a law. In my opinion none of these general rules is entirely correct or entirely wrong. The obligation or the contract may belong to a local sphere of social life, and in such a case-and only 
in such a case-the juridical relation between creditor and debtor is governed by the law of the said local sphere. The place of contracting, that of performance and the other points of contact are only expedients, which may be of use when an obligation is connected with a local sphere of social life. If such a connection cannot be found, every mechanical general rule is to be avoided, the only reasonable principle being that the obligation or the contract, in such a case, is governed by the rules of the international-common law, if such rules exist, and, in default thereof, by the rules derived directly from the requirements of a sound international-social intercourse between individuals. The rules last mentioned must be found by the courts in accordance with common sense. In many cases, where not even a silent expression of the intention of the parties can be ascertained, the courts are obliged to use their own common sense, in order to determine what the parties to a contract would have had in view, if they had taken counsel with their common sense. It would be an advantage if the nations, assembled at a conference, would refrain from any general solution of the conflict of laws in the matter of obligations and contracts, a golden silence being preferable to a silver mechanical rule. I am aware of the fact that international-common rules are not always to be found and that an appeal to common sense is not free from vagueness, but the nations, silent as to the conflict of laws, are able to speak loudly, with regard to another department of private international law, that of the uniform national laws, containing exhaustive or nearly exhaustive regulations. Before the great war attempts in this direction were made, partly with success. The international transportation of goods by rail, and the law relating to collisions and to assistance at sea have been the object of detailed regulations. Other subjects are nearly ripe for international uniformity, for instance the law relating to bills of exchange. Such a uniformity is as desirable after the great war as it was before. With a small but important amendment the system applied in the draft-treaty of the Hague concerning bills of exchange would be useful. Instead of undertaking to put into effect by treaty national laws of a fixed type, the nations should assume only the obligation to make serious efforts to adopt such a law. Such a limited obligation would be universally acceptable.

Civil procedure and connected matters. In the matters pointed out in the rubric, solutions of conflicts of laws are not so necessary as positive international-common rules. A treaty, concluded at the Hague in 1896 and revised in 1905 , has regulated a few points. It has been confined to questions, which could be considered at that time as ripe for solution, viz., the service of summons in foreign countries, letters rogatory, security for costs called (improperly) judicatum solvi, the rights of foreign indigents and the imprisonment of aliens for debt. The regulations are not perfect, but nobody will deny their importance or question their perfectibility. The regulation of the form of summons 
directed to defendants domiciled abroad, can certainly be improved. The optional form could be made obligatory. Since the great war, the international postal service has quickly become as reliable as it was before, so that summons or legal notice by registered letter can be generally admitted, provided that such summons would not be a sufficient basis for an internationally recognized jurisdiction. I beg to add that the question of internationally recognized jurisdiction is the foundation-stone of the international law of civil procedure. Only if the foreign court, which has pronounced a judgment, is in possession of such a jurisdiction with regard to the dispute, ought the judgment to be recognized everywhere as a determination of the point of law and enforced eventually. The same condition of jurisdiction is the basis of the international bankruptcy law. But, in our days, it would be a vain endeavor to establish an exhaustive international regulation of the jurisdiction in civil matters. In many countries the jurisdiction of the national judiciary is extended beyond measure, in the interest of their own subjects acting as claimants and it is not to be expected that the lawgivers will give up such regulations. I dare say that a way out of this difficulty will be found. An international agreement could be limited to a regulation of the cases in which the jurisdiction of a national judiciary in civil matters would be internationally recognized. According to the nature of disputes, the domicil of the defendant and the situation of a thing could afford bases of recognized jurisdiction. Each nation would, in this way, remain free as to the national regulation of jurisdiction, but only in the cases, fixed by the international agreement, would the recognition and the enforcement of foreign judgments be secured. The same system could be followed with regard to adjudications in bankruptcy.

Conchusions. I come to the following conclusions. The importance of private international law will not disappear. A form, suitable for universal agreements, can be found, As to the contents of such agreements, a distinction ought to be made between family law, law of obligations and law of civil procedure, and in each of the three categories, many points, consisting not exclusively of solutions of conflicts of laws, can be fixed by a supranational regulation. In this way the civil work of the Hague can be consolidated, extended and brought to the relative perfection attainable by human power.

The present rules of enforcement prevailing in practically all the nations of the worid are discussed by Lorenzen in (19I9) 29 YALE LAW JouRNAI, I88; and (1920) ibid., 268. 